Uludag Univ. J. Fac. Vet. Med.

32 (2013), 1: 39-45

\title{
Geçiş Dönemindeki Süt Sığırlarında Karaciğer Yağlanması ve Kolinin Önemi
}

\author{
Yavuz MERAL $^{*} \quad$ Çağdaş KARA*
}

Geliş Tarihi: 16.09.2013

Kabul Tarihi: 22.10.2013

\begin{abstract}
Özet: Artan dünya nüfusu ve gelişen süt sığırcılığı endüstrisine paralel olarak, süt sığırlarının beslenmesinde yem katkı maddelerinin kullanım alanı ve miktarı artmışıır. Metabolik ve reprodüktif bozuklukların en çok gözlendiği dönem, doğum öncesi ve sonrasındaki 3 haftayı kapsayan geçiş dönemidir ve bu süreç, bir süt sığırının yaşam döngüsü içerisindeki en önemli dönem olarak kabul edilmektedir. Günden güne büyüyen süt sığırcılığı endüstrisinde hastalıkları tedavi etmekten çok hastalığın ortaya çıkışını önlemek önem kazanmıştır. Büyük verim kayıplarına ve tedavi maliyetlerine yol açan özellikle geçiş döneminde gözlenen yağlı karaciğer sendromunun önlenmesinde, geçiş dönemindeki yüksek verimli süt sığırı rasyonlarına rumenden korunmuş kolin ilavesi umut verici bir besleme stratejisi olarak değerlendirilmektedir.
\end{abstract}

Anahtar Kelimeler: Süt sığırlarının geçiş dönemi, karaciğer yağlanması, kolin.

\section{Fatty Liver and İmportance of Choline During the Transition Period of Dairy Cattle}

\begin{abstract}
Usage area of some feed additives is on the rise in parallel to increasing world population and developing dairy cattle industry. Transition period (approximately three weeks each before and after calving) is clearly the most important period of a dairy cow's life cycle, by reason of a large number of metabolic and reproductive disorders are occurred in the transition period. In growing dairy cattle industry it is more important to prevent metabolic and reproductive disorders than treating them. Especially for preventing fatty liver syndrome which is generally occurred in transition period and resulted with excessive costs of treatment, addition of rumen protected choline to high yielding dairy cow rations seems to be a promising nutrition strategy.
\end{abstract}

Key Words: The transition period of dairy cattle, fatty liver, choline.

\section{Giriș}

Süt sığırları, son 50-60 yıldan beri daha fazla süt verimi elde etmek amaciyla genetik seleksiyona tabi tutulmuş ve daha iyi bakımbeslenme şartları uygulanarak süt verimlerinde artışlar sağlanmıştır. Sağlanan genetik ilerleme ile birlikte süt veriminin artması sonucu, geçiş döneminde görülen hastalıklarda da (yağlı karaciğer, ketozis, süt humması, meme ödemi, retensiyo sekundinarum, metritis, abomazum deplasmanı, asidozis, laminitis) artış ve döl veri- minde problemler meydana gelmiştir ${ }^{22}$. Bu durumun temel sebebi, yüksek süt verimine sahip ineklerde yaşama payı ve süt üretimi için gerekli olan enerji miktarının, tüketilen rasyon ile sağlanamaması sonucu enerji dengesinin bozulmasıdır. Verim düzeyleri farklı olan hayvanların yaşama payı enerji ihtiyaçları hemen hemen aynıyken verim payı enerji ihtiyaçları arasında büyük farklılıklar gözlemlenmektedir. $\mathrm{Bu}$ fark, verim düzeyi yüksek hayvanlarda besleme ile sağlanabilecek enerji dengesinin önemini özetlemektedir ${ }^{7}$. Artan dünya nüfusu ile paralel

Uludağ Üniversitesi Veteriner Fakültesi Hayvan Besleme ve Beslenme Haslıkları A.D. Görükle Kampüsü, Nilüfer/BURSA. yavuzmeral@uludag.edu.tr 
olarak artan hayvansal ürün talebini karşılamak adına, yüksek verimli süt sığırlarının yetiştirilmesi ve mevcut ırkların daha etkin kullanılması kaçınılmaz bir hale gelmiștir. Bunlara ek olarak, günümüzde artan çevre kirliliğinin hayvansal üretim açısından daha az sayıda ve daha yüksek verimli hayvanların yetiştirilmesi ile azaltılabileceği düşünülmektedir ${ }^{7}$.

Geçiş döneminde bulunan süt sığırlarında büyük çaplı metabolik değișimler olmaktadır. Bu dönemdeki temel besleme stratejisi, meydana gelen metabolik değişikliklere adaptasyonun sağlanmasıdır. Geçiş döneminde besleme yönetimi açısından başlıca yapılması gerekenler, doğumdan önceki 3 hafta boyunca kademeli olarak erken laktasyon rasyonuna geçişin sağlanması ve doğum sonrası erken laktasyon döneminde (ilk 10 hafta) artan enerji ve besin maddesi ihtiyacının karşılanmaya çalıșılmasıdir ${ }^{17}$. Geçiş döneminde karşılanamayan enerji ihtiyacı ya da diğer adıyla negatif enerji dengesi, erken laktasyondaki süt sığırlarında sağlık parametreleri ve reprodüktif performansı negatif etkileyerek ekonomik kayıplara neden olmakta$\mathrm{d}_{1}{ }^{15}$. Bu yüzden geçiş döneminin karlılık aç1sından, bir süt sığırının yaşam döngüsünün en önemli süreci olduğu unutulmamalıdır.

Geçiş dönemindeki süt sığırlarında gözlemlenen hastalıkların büyük ölçüde azaltılması, uygun ve dengeli besleme programlarının uygulanmasına bağlıdır. Yüksek verimli süt sığırlarında geçiş döneminde görülen hastalıkların önlenmesi adına dengeli rasyonların düzenlenmesinin yanı sıra, bazı yem katkı maddelerinin kullanımı da giderek önem kazanmaya başlamıştır. Bu katkı maddelerinden birisi, son yıllarda kullanım alanı giderek artan korunmuş (rumende yıkımlanmayan) kolindir. Günümüze kadar ruminant besleme açısından kolin, esansiyel bir besin maddesi olarak değerlendirilmemiștir. Ancak duodenal içerikteki kolinin toplam öngörülen ihtiyacın sadece \%30' unu karş1layabildiği belirlenmiştiir ${ }^{11}$.

\section{Kolinin Tanımı ve Metabolizmadaki Başlıca Görevleri}

Kolin, geçmişte B grubu vitaminler arasında değerlendirilmiş olsa da, fonksiyonları itibarı ile tam olarak B kompleks vitaminlerin tanımına uymamaktadır ${ }^{19}$. Çünkü kolin, endojen olarak sentezlenebilmektedir ve kolinin bir enzim kofaktörü olduğuna dair herhangi bir kanıt bulunmamaktadır. Bununla birlikte diğer suda çözünen vitaminlerin aksine, kolinin metiyonin, folik asit ve vitamin $B_{12}$ ile yakın ilişkisi bu- lunmaktadır. $\mathrm{Bu}$ yüzden kolinin yetersizlik semptomlarını teşhis etmek oldukça zordur ${ }^{28,33}$. Ancak metabolizmada, hücre membranında bulunan bir fosfolipid olan lesitinin ve bir nörotransmiter madde olan asetilkolinin yapisal unsuru olduğundan dolayı diğer vitaminlere kıyasla koline daha yüksek miktarlarda ihtiyaç duyulmaktadır. Ayrıca kolin, bazı metilasyon reaksiyonlarında metil grubu vericisi olarak görev almaktadır. Kolin yetersizliği, karaciğerden dokulara yağların taşınması için gerekli olan fosfolipidlerin yetersizliği sebebi ile karaciğerde yağ birikimine sebep olabilmektedir ${ }^{26}$.

Kolin, vücutta önemli işlevleri bulunan iki molekülün (fosfatidilkolin ve asetilkolin) sentezlenmesinde anahtar rol oynamaktadır ve metabolizmadaki en önemli metil donörlerinden birisidir. Kolinin metabolizmadaki görevleri aşağıdaki gibi sıralanabilmektedir ${ }^{27}$.

1. Fosfatidilkolin, ruminantlardaki temel fosfolipidtir ve lipid absorbsiyonu, transportu, hücre membran1, lipoprotein sentezi ve hücresel iletim için kritik bir öneme sahiptir. Kolin, lipotropik bir etkiye sahip olmasından dolayı karaciğerde yağ birikimini engellemektedir.

2. Kolinden sentezlenen bir diğer metabolit olan asetilkolin ise merkezi ve periferal sinir sisteminde yer alan bir nörotransmiterdir ve kas kontraksiyonları için esansiyeldir. Asetilkolin, nöronlarda kolin ve asetil-CoA'dan sentezlenmektedir. Kolin, nörotransmiter ve fosfolipidlerin sentezinde önemli bir rol oynadığ 1 için hücre membranında iletimi, yapısal bütünlüğü ve kolinerjik nörotransmisyonu desteklemekte, hücre duvarında kolinerjik yapısal bütünlüğü doğrudan etkilemektedir.

3. Metabolizmadaki en önemli iki metil donörü bir kolin metaboliti olan betain ve bir metiyonin metaboliti olan S-adenosil-metiyonin (SAM)'dir. Kolin, metilasyon yolları için betain üzerinden metil gruplarının ana kaynağını oluşturmaktadır. Metiyonin ve kolin, metil donörü olarak görev yapmaları sebebi ile metabolik olarak oldukça yakın ilişki içerisindedir. Süt sığırlarında karşılanamayan kolin ihtiyacı SAM tarafindan sağlanan metil grupları ile fosfatidiletanolaminin siralı metilasyonu üzerinden gerçekleștirilen de novo sentez ile karşılanmaktadır (Şekil-1). Buna rağmen, de novo sentez yoluyla fosfatidilkolin sentezi için yeterli miktarda metil donörünün üretilmesi ve böyle bir metilasyon yolunun mevcudiyeti, besin maddesi ihtiyac1 artan yüksek süt verimli ineklerde optimum sağlık verim parametrelerini sağlayacak kadar kolin sentezlendiği anlamına gelmemektedir. 


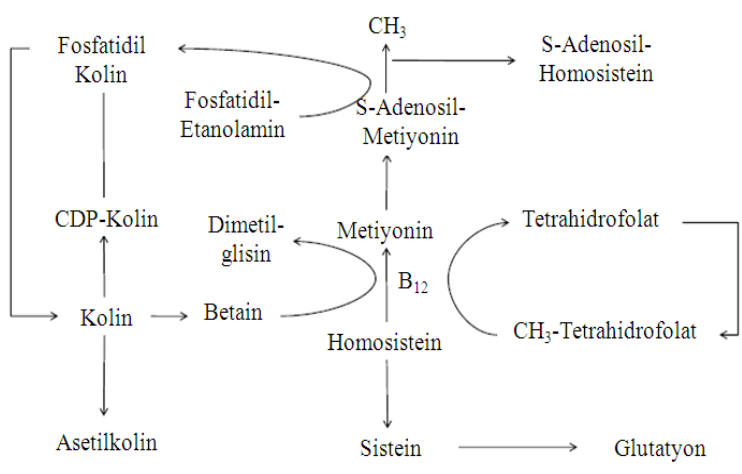

Şekil-l: Kolinin de novo sentezi

Figure-1: De novo synthesis of choline

\section{Kolinin Rumen Metabolizması}

Kolinin korunmamış formları, rumen mikroorganizmaları tarafından büyük ölçüde parçalanmaktadır. Bu yüzden, süt sığırlarının kolinin korunmamıs formları bakımından zengin rasyonlarla beslenmesi (kolince zengin hammaddeler ve ya korunmamış kolin klorit) sonucu, ince barsağa geçen kolin miktarındaki artış çok az olmaktadır ${ }^{8,21}$. Yapılan çalışmalarda, arpa, pamuk tohumu küspesi, balık unu ve soya fasulyesi küspesinde bulunan kolinin ve korunmamış formdaki kolin stearat ve kolin kloritin rumende yıkımlanma oranlarının sırası ile $79.4,84.7,82.9,83.8,98.0$ ve $98.6 \%$ olduğu bildirilmiştir $^{30}$. İnce barsaklara ulaşan kolin, genellikle fosfatidilkolin formundadir ve rumen mikroorganizmaları (özellikle prootozalar) tarafindan sağlanmaktadır ${ }^{6}$. Geçiş döneminde bulunan yüksek verimli süt sığırlarına sunulan rasyonlardaki konsantre yem oranının yüksek olduğu ve bu durumun rumendeki protozoa varl1ğını negatif etkilediği düşünülürse özellikle bu dönemde korunmuş kolin ihtiyacının daha fazla artacağı kolayca anlaşılabilmektedir.

Korunmamış kolin formlarının günümüzde önemi giderek artan ruminal metan üretimi ile de ilişkisi bulunmaktadır. Ruminal ve enterik metan üretiminin beslenmeden etkilendiği bilinen bir gerçektir. Ruminantlar tarafindan üretilen ve bir sera gazı olan metan, hem çevresel kirliliğe yol açmakta hem de hayvan tarafindan sindirilen brüt enerjinin \% 2-12'sininin metan ile vücuttan atılması sebebiyle enerji kaybı olarak değerlendirilmektedir ${ }^{16}$. Rasyonla alınan korunmamış kolinin metil grupları, yeterli substrat varlığında rumen mikroorganizmaları tarafından trimetilamine, oluşan trimetilamin ise daha sonra metana metabolize edilmektedir. Ancak trimetilaminin metana metabolizması tamamen yeterli substrat varlığ ile ilişkilidir ve ortamda yeterli substrat olmadığ 1 zaman, metana metabolize edilemeyen trimetilamin rumende birikmektedir. Trimetilaminin, kolinin metana dönüşümü sırasında kullanılan metil grupları için tek aracı olduğu bilinse de, metilamin de metan üretimi için bir substrat görevi görmektedir. Ayn zamanda metiyoninin metil grubu da metana dönüştürülebilmektedir ${ }^{21}$.

\section{Geçiş Döneminde Gözlenen Karaciğer Yağlanmasının Oluşum Mekanizması ve Kolin İle İlişkisi}

Metabolizmanın karşılanamayan enerji ihtiyacını adipoz dokuda bulunan yağ asitlerinden karşılaması doğal bir biyolojik yöntemdir ${ }^{1}$. Erken laktasyon döneminde artan enerji ihtiyacının rasyonla karşılanamaması sonucu bu dönemdeki yüksek verimli süt sığırlarında negatif enerji dengesi ortaya çıkmaktadır. Metabolizma, bozulan enerji dengesini vücut yağlarını (esterleşmemiş yağ asitleri; EYA) mobilize ederek düzeltmeye çalışır. Bu süreçte kandaki EYA seviyesi artmakta ve bu lipid yapılar farklı dokularda farklı şekillerde değerlendirilmektedir ${ }^{2}$. Ayrıca karaciğerde EYA seviyesinin yükselmesi, hepatositlerde lipogenezis ve ketogenezisi de arttırmaktadır. Ancak karaciğerde EYA'nın oksidasyonu kandaki konsantrasyonuyla orant1lıdır ve oksidasyon sınırlıdır. Yağlı karaciğer sendromu, geçiş döneminde bulunan yüksek verimli süt sığırlarının neredeyse yarısında gözlenmektedir ${ }^{4}$.

Genellikle, memelilerde 2 tip lipoprotein (Şilomikronlar ve Çok Düşük Dansiteli Lipoprotein; ÇDDL), trigliserid transportundan sorumludur. Ruminantlarda plazma ÇDDL konsantrasyonu oldukça düşüktür ve özellikle laktasyon döneminde, karaciğer harici dokular için temel lipid kaynağı olarak değerlendirilmektedir. Sütteki uzun zincirli yağ asitlerinin kaynağ kandaki ÇDDL formundaki trigliseritlerdir. $\mathrm{Bu}$ trigliseritler, yemle alınan yağ kaynaklarından veya adipoz dokudan mobilize edilen lipid yap1lardan köken almaktadır. Laktasyonun erken döneminde, negatif enerji dengesi ile birlikte adipoz dokudaki lipoliz artmaktadır. Daha önce de belirtildiği gibi, bu dönemde yağ mobilizasyonu, kandaki EYA konsantrasyonunu yükseltmekte ve EYA karaciğer tarafindan keton cisimciklerine (beta hidroksi bütirat, asetoasetat, aseton) ya da esterifiye trigliseritlere metabolize edilmektedir. Trigliseritler karaciğerde normalde ÇDDL formunda depolanır ya da uzaklaştırılırlar. Ancak özellikle erken laktasyon döne- 
minde karaciğere gelen EYA miktarının hızla artması, karaciğerde ÇDDL oluşumunun hızla artacağ 1 anlamına gelmemektedir. ÇDDL üretiminin hızla artamamasının sebebi ÇDDL üretimi için esansiyel olan yapıların (kolesterol, fosfatidilkolin, apolipoproteinler) yetersiz sentezi olabilmektedir. Geçiş döneminde bulunan süt sığırlarında karaciğer yağlanmasının ortaya çıkış sebebi, karaciğere metabolize edebileceğinden fazla miktarda yağ mobilizasyonu olmas1 ve bu aşamada lipotropik maddelerin (kolin ve metiyonin) yetersizliği olarak özetlenebilir ${ }^{24}$. Yağlı karaciğerin oluşum mekanizması ve kolinin bu metabolizmadaki yeri Şekil-2 de şematize edilmiştir ${ }^{31}$.

Karaciğere yağ infiltrasyonu ve karaciğer fonksiyonlarının sekteye uğraması, süt sığırları için büyük önem arz etmektedir. Çünkü süt sığırlarında, metabolizmanın ihtiyaç duyduğu glikozun \% 85'i karaciğerde elde edilmektedir. Aynı zamanda karaciğerin fertilite, immunite ve yem tüketiminin düzenlenmesi üzerindeki merkezi rolü, bu organın önemini özetlemektedir. Karaciğerin yağlanma şiddeti ile genel sağlık durumu ters orantılı olarak etkilenmekte (Tablo1) ve karaciğer yağlanmas1, reprodüktif ve metabolik bozukluklara (Tablo-2) neden olmaktadir ${ }^{4}$.

Tablo-1: Karaciğer yağlanmasının şiddetine göre sınıflandırılması ve genel sağlık durumu ile reprodüktif performansa etkisi

Table-1: Classification of fatty liver severity and effects of fatty liver to health status and reproductive performance

\begin{tabular}{|l|c|c|l|}
\hline Sınıflandırma & $\begin{array}{c}\text { Karaciğer- } \\
\text { deki TG* } \\
\text { miktarı } \\
\text { (yaş ağırı- } \\
\text { ğın \%'si) }\end{array}$ & $\begin{array}{c}\text { Sağlık duru- } \\
\text { mu ve } \\
\text { reprodüktif } \\
\text { performans }\end{array}$ & $\begin{array}{l}\text { Karaciğerin } \\
\text { durumu }\end{array}$ \\
\hline Normal & $<1 \%$ & 0 & $\begin{array}{l}\text { Normal, } \\
\text { yağlanma yok }\end{array}$ \\
\hline $\begin{array}{l}\text { Yağlı Karaciğer } \\
\text { Hafif şiddetli }\end{array}$ & $1-5 \%$ & + & $\begin{array}{l}\text { Sentrilobüler } \\
\text { TG } \\
\text { infiltrasyonu }\end{array}$ \\
\hline $\begin{array}{l}\text { Yağlı Karaciğer } \\
\text { Orta şiddetli }\end{array}$ & $5-10 \%$ & ++ & $\begin{array}{l}\text { Karaciğerin } \\
\text { tamamına TG } \\
\text { infiltrasyonu }\end{array}$ \\
\hline $\begin{array}{l}\text { Yağlı Karaciğer } \\
\text { Şiddetli }\end{array}$ & $>10 \%$ & +++ & $\begin{array}{l}\text { Büyümüş, } \\
\text { nekrotik } \\
\text { karaciğer }\end{array}$ \\
\hline
\end{tabular}

${ }^{*}$ TG: Trigliserit

** “ + " işareti sayısı arttıkça sağlık durumu ve reprodüktif performans kötüleşmektedir
Tablo-2: Karaciğer yağlanması ile metabolik hastalıklar ve reprodüktif performans arasındaki ilişki

Table-2: Relationship of fatty liver with metabolic disorders and reproductive performance

\begin{tabular}{|c|c|c|c|}
\hline $\begin{array}{l}\text { Metabolik } \\
\text { Bozukluklar }\end{array}$ & İlişki & $\begin{array}{l}\text { Reprodüktif } \\
\text { Performans }\end{array}$ & İlişki \\
\hline $\begin{array}{l}\text { Abomasum deplas- } \\
\text { manı }\end{array}$ & +++ & İlk ovaryum aktivitesi & ++ \\
\hline $\begin{array}{l}\text { Bağışıklık sistemi } \\
\text { bozukluğu }\end{array}$ & ++ & illk ovulasyon & + \\
\hline Ketosis & +++ & illk östrus & + \\
\hline Laminitis & + & illk tohumlama & + \\
\hline Mastitis & ++ & Açık gün sayısı ${ }^{* *}$ & ++ \\
\hline Metritis & ++ & Gebelik oranı & ++ \\
\hline Süt Humması & + & $\begin{array}{l}\text { Gebelik başına düşen } \\
\text { tohumlama sayısı }\end{array}$ & + \\
\hline $\begin{array}{l}\text { Retensiyo Sekundina- } \\
\text { rum }\end{array}$ & + & & \\
\hline
\end{tabular}

* “ + " işaretinin sayısı negatif etki düzeyini temsil etmektedir.

${ }^{* *}$ Buzağılamadan sonra tekrar gebe kalıncaya kadar geçen süre

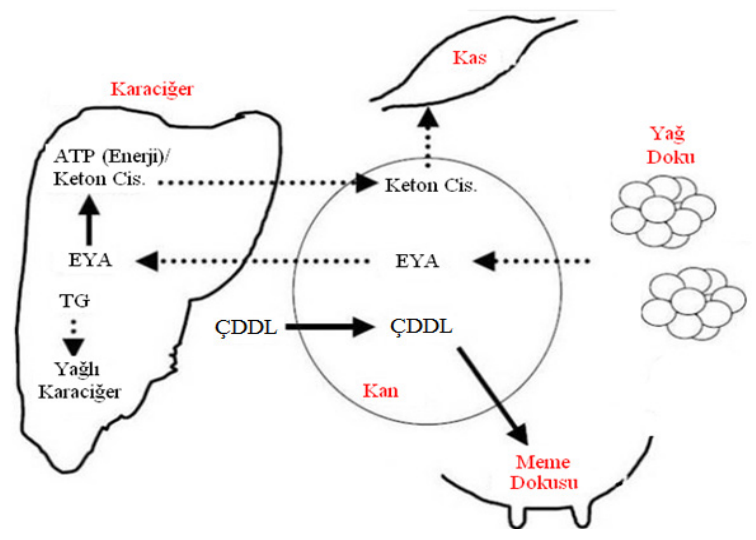

Şekil-2: Yağlı karaciğerin oluşum mekanizması ve kolinin bu metabolizmadaki yeri ${ }^{21}$

Figure-2: Fatty liver mechanism and choline's mode of action

\section{Kullanımı \\ Süt Sı ğırı Beslenmesinde Kolin}

Süt sığırlarının rasyonlarına yem katkı maddesi olarak kolin ilave edilmesi üzerine yapılan ilk çalışmalarda, rumen fermantasyonundan korunmamış kolinin, süt verimini ve kompozisyonunu pozitif yönde etkilediği gözlemlenmiştir. Erdman ve ark. ${ }^{12}$ yaptıkları çalışmada, laktasyondaki süt sığırı rasyonlarına korunmamış kolin ilavesinin, süt yağını ve \% 4 yağa göre düzeltilmiş süt verimini pozitif etkilediğini ve kolinin lipotropik etkisi ile düşük süt yağ1 sendromunu engellemede kullanılabileceğini bildirmişlerdir. Bununla beraber kolinin, 
rumen $\mathrm{pH}$ 's1 ve asetat: propiyonat oranı üzerine etkili olmadığını ve süt yağındaki artışın, kolinin rumendeki fermantasyonu düzenlenmesi ile değil karaciğer aracılığı ile (adipoz dokudan meme dokuya yağ transportu ile) sağlandığı sonucuna varılmıştır. Ancak daha sonra yapılan çalışmalarda, süt sığırı rasyonlarına yapılan korunmamış kolin ilavesinin süt verimi ve kompozisyonunda bir değişime sebep olmadığı ve bunun da, kolinin korunmamış formlarının rumende hızlı bir şekilde yıkımlanmasından kaynaklandığı bildirilmiştir ${ }^{3,27}$. Buna ek olarak, süt sığırı rasyonlarına kolinin korunmamış formlarının fazla miktarlarda (280 gr/gün ve üzeri) ilave edilmesi ile yem tüketiminin negatif etkilendiği (18.4 kg/gün'den 16.7 kg/gün'e azalma), rasyondaki sentetik korunmamış kolin miktarının 23 g/gün'den 326 g/gün'e yükseltilmesinin, duedonal içerikteki kolin miktarını 1.2 g/gün'den sadece 2.5 g/gün'e çıkarttığı bildirilmiştir ${ }^{29}$. Erdman ve ark. ${ }^{12}$ 'n yaptıkları çalışmada, rasyona kolin ilavesi ile plazma EYA seviyesinde düşüş saptanırken, Bonomi ve ark. ${ }^{5}$ yaptıkları çalışmada rasyona korunmamış kolin ilavesi ile plazma EYA seviyesinde artı̧̧ gözlemlenmiştir. Sharma ve $\operatorname{Erdman}^{29}$ geç laktasyon döneminde bulunan süt sığırlarının rasyonlarına yüksek dozda korunmamış kolin ilave edilmesi ile kuru madde tüketimi ve rumen propiyonat oranında azalma, rumen amonyak oranında iste artış saptadıklarını bildirmişlerdir. Yapılan çalışmalardan elde edilen sonuçlar, bilim adamlarını, kolinin rumen fermantasyonundan korunmuş formlarını araştırmaya teşvik etmiştir.

Bilim adamları, 1990 yıllarının başlarından itibaren süt sığırı rasyonlarına rumenden korunmuş kolin (RKK) ilavesinin etkilerini araştırmaya başlamışlardır. Bu konu ile ilgili yapılan araştırmaların sonuçları incelendiğinde, özellikle geçiş ve erken laktasyon döneminde bulunan süt sığırı rasyonlarına RKK ilave edilmesinin, üretim miktarı ve niteliğinin iyileştirilmesi ve negatif enerji dengesinin giderilmesi açısından pozitif etkilere yol açtı̆̆ açıkça gözlenmektedir. Yapılan birçok çalışmanın sonuçlarına göre, geçiş ve erken laktasyon dönemlerinde bulunan süt sığırlarının rasyonlarına RKK ilavesi ile süt veriminde artış, $50,11,14,25$ gözlemlenmiștir. Bu çalıșmaların bazılarında sütün yă kompozisyonunda da artış gözlenirken ${ }^{5,10}$, Elek ve ark. ${ }^{9}$ ve Piepenbrick ve Overton ${ }^{23}$ yaptıkları çalışmalarda süt sığırı rasyonlarına RKK ilavesinin sütün yağ kompozisyonunu etkilemediğini tespit etmişlerdir. Yapılan diğer çalışmalarda süt sığırı rasyonlarına RKK ilavesinin, karaciğerde yağ asidi metabolizmasında ${ }^{23}$, ÇDDL sentezi ve glikojen içeriğinde ${ }^{13}$ artışa, plazma EYA seviyelerinde $^{5,24,25}$ ve karaciğerdeki TG miktarında azalmaya ${ }^{13}$ yol açtığ $\operatorname{larda}^{23,34}$ ise plazma EYA seviyesi, RKK ilavesinden etkilenmemiştir. Mohsen ve ark. ${ }^{20}$ laktasyonun 8. haftasında bulunan süt sığırları üzerinde gerçekleştirdikleri çalışmada, rasyona 0 , 15 ve 30 gram/gün dozlarında RKK ilavesi ile rumen $\mathrm{pH}$ 's1, amonyak azotu düzeyi ve toplam uçucu yağ asitleri kompozisyonu parametreleri etkilenmeksizin, sindirilebilirlik, toplam sindirilebilir besin maddeleri ve sindirilebilir protein tüketimi parametrelerinde iyileşme gözlemlediklerini bildirmişlerdir. Aynı çalışmada RKK ilavesinin karlılığ da pozitif etkilediği bildirilmiştir.

Süt sığırlarında, farklı laktasyon dönemlerinde yapılan performans çalışmalarına ek olarak özellikle geçiş döneminde bulunan süt sığırları rasyonlarına RKK ilavesinin metabolik ve reprodüktif parametreler üzerine etkilerini inceleyen çalışmaların sonuçları da dikkat çekicidir. Lima ve ark. ${ }^{18}$ geçiş döneminde bulunan süt sığırlarının rasyonlarına kolin ilave edilmesinin, bu dönemde en çok gözlenen metabolik ve reprodüktif bozukluklar üzerine etkilerini incelemek amacı ile geniş çaplı bir çalışma gerçekleştirmişlerdir. $\mathrm{Bu}$ çalışmanın birinci kısmında, 369 süt sığırının rasyonlarına prepartum 25 . günden, postpartum 80 . güne kadar $15 \mathrm{~g} /$ gün RKK, ikinci k1smında ise 578 gebe düvenin rasyonlarına, beklenen doğum tarihinden 21 gün önceden doğuma kadar $15 \mathrm{~g} /$ gün RKK ilave edilmiştir. Çalışmanın ilk kısmında, doğum öncesi deneme (RKK+) ve kontrol (RKK-) grupları arasında kuru madde tüketimi açısından fark yokken, doğum sonrası dönemde deneme grubundaki hayvanlarda, kuru madde tüketiminde artış eğilimi olduğu gözlenmiştir. Ayrıca deneme grubunda klinik ketozis $(P<0.01)$, mastitis $(P<0.06)$, toplam morbidite $(P<0.001)$ ve mastitis oluşumu $(P=0.02)$ azalmış, gebelik başına düşen suni tohumlama sayısı ve siklik aktivite parametreleri denemeden etkilenmemiştir. Çalışmanın gebe düveler üzerinde gerçekleştirilen ikinci kısmında ise laktasyonun ilk 80 gününde, deneme grubundaki hayvanların süt verimlerinde artış eğilimi $(P=0.07)$ gözlenmiştir. Ayrica deneme grubundaki retensiyo sekundinarum $(P=0.004)$ ve mastitis $(P=0.04)$ vakalarının daha az gözlemlendiği, klinik ketozis, abomasum deplasmanı ve mastitis oluşumunun denemeden etkilenmediği bildirilmiştir. 
Karaciğer yağlanması, geçiș döneminde bulunan yüksek verimli süt sığırlarında sıklıkla gözlenen ve yol açtığı veya birlikte seyrettiği metabolik bozukluklar göz önünde bulundurulduğunda, süt sığırı endüstrisi açısından büyük önem arz eden bir hastalıktır. Yağlı karaciğer sendromunda morbidite yaklaşık \% 82, mortalite oranı ise $\% 25$ olarak belirlenmiştir ${ }^{32}$. Karaciğer yağlanmasının yol açtığı ve birlikte seyrettiği metabolik bozuklukların kompleks bir yapı göstermesi ve bu durumun süt ve reprodüktif verim kaybına yol açması nedeniyle, yağlı karaciğer sendromu işletme karlılığını büyük oranda negatif yönde etkileyebilmektedir. Yapılan bir çalışmada, yüksek verimli süt sığırlarında gözlenen ve yağlı karaciğer ile yakından ilişkili metabolik bir hastalık olan ketozisin, tedavi maliyetinin inek başına 145 Amerikan doları olduğu bildirilmiştir. Amerika'da 9 milyon süt sığırı bulunduğu ve sadece ketozisin senelik toplam 60 milyon dolardan daha fazla zarara yol açtı̆̆ hesaplanmıştır ${ }^{4}$. Ülkemizde bulunan yaklaşık 4.5 milyon süt sığırının verim seviyeleri Amerika'da bulunan hayvanlar kadar yüksek olmasa da, basit bir hesaplama ile Türkiye için (sadece ketozis kaynaklı) bahsedilen kaybın 2030 milyon dolar civarında olabileceği ortaya çıkmaktadır. Aynı zamanda yağlı karaciğer sendromunun neden olduğu diğer metabolik ve reprodüktif bozuklukların tedavi maliyetleri ve verimde gözlenen düşüşler, maddi kayıpların boyutlarının ne kadar ciddi olabileceğini gözler önüne sermektedir.

Sonuç olarak yağlı karaciğer sendromunun rasyonda yapılacak müdahaleler ile önlenmesi ya da şiddetinin azaltılması, verim kayıplarının önüne geçilebilmesi ve tedavi masraflarının ortadan kaldırılabilmesi adına büyük önem taşımaktadır. Yapılan çalışmaların sonuçları incelendiğinde, geçiş döneminde bulunan süt sığırlarının rasyonlarına yapılacak $15 \mathrm{gr} / \mathrm{gün}$ RKK ilavesinin, bu dönemde gözlenen süt verim kayıplarının, metabolik ve reprodüktif rahatsızlıkların görülme oranının azaltılmasında ümit verici bir besleme stratejisi olarak değerlendirilebileceği sonucuna varılmıştır.

\section{Kaynaklar}

1. Ametaj, B.N., Bradford, B.J., Bobe, G., Nafikov, R.A., Lu, Y., Young, J.W., Beitz, D.C., 2005. Strong relationships between mediators of the acute phase response and fatty liver in dairy cows. Can. J. Anim. Sci., 85, 165-175.

2. Arslan, C., Tufan, T., 2010. Geçiş dönemindeki süt ineklerinin beslenmesi II. Bu dönemde görü- len metabolik hastalıklar ve besleme ile önlenmesi. Kafkas Univ. Vet. Fak. Derg., 16(1), 159-166.

3. Atkins, K.B., Erdman, R.A. Vandersall J.H., 1988. Dietary choline effects on milk yield and duodenal choline flow in dairy cattle. J. Dairy Sci., 71, 109-116.

4. Bobe, G., Young, J. W., Beitz, D. C., 2004. Invited Review: Pathology, etiology, prevention, and treatment of fatty liver in dairy cows. J. Dairy Sci., 87, 3105-3124.

5. Bonomi, A., Quarantelli, A., Bonomi, B.M., Sabbioni, B., Superchi, P., 1996. Inclusion of rumenprotected choline in diets for dairy cattle. Effect on productive and reproductive efficiency (İngilizce özetli İtalyanca). Rivista di Scienza dell'Alimentazione, 25, 413-434.

6. Broad, T.E., Dawson, R.M., 1976. Role of choline in the nutrition of the rumen protozoon Entodinium caudatum. J. Gen. Microbiol., 92, 391397.

7. Capper, J. L., Cady, R.A., Bauman D.E., 2008. Increased production reduces the dairy industry's environmental impact. In: Proceedings. Cornell University, ABD, pp. 55.

8. Dawson, R.M.C., Grime, D.W., Lindsay, D.B., 1981. On the insensitivity of sheep to the almost complete microbial destruction of dietary choline before alimentary-tract absorption. Biochemical Journal, 196, 499-504.

9. Elek, P., Newbold, J. R., Gaal, T., Wagner, L., Husveth , F., 2008. Effects of rumen-protected choline supplementation on milk production and choline supply of periparturient dairy cows, Animal, 2, 11, 1595-1601.

10. Erdman, R.A., 1994. Production responses in field study herds fed rumen protected choline. J. Dairy Sci., 77 (1), 186 Abstr.

11. Erdman, R.A., Sharma, B.K., 1991. Effect of dietary rumen-protected choline in lactating dairy cows. J. Dairy Sci., 74, 1641-1647.

12. Erdman, R.A., Shaver, R.D., Vandersall, J.H., 1984. Dietary choline for the lactating cow: possible effects on milk fat synthesis. J. Dairy Sci., 67, 410-415.

13. Goselink, R.M.A., van Baal, J., Widjaja, H.C.A., Dekker, R.A., Zom, R.L.G., De Veth, M.J., Van Vuuren, A.M., 2012. Effect of rumen-protected choline supplementation on liver and adipose gene expression during the transition period in dairy cattle, J. Dairy Sci., 96, 1102-1116.

14. Hartwell, J.R., Cecava, M.J., Donkin, S.S., 2000. Impact of dietary rumen undegradable protein and rumen-protected choline on intake, peripartum liver triacylglyceride, plasma metabolites and milk production in transition dairy cows. J. Dairy Sci. 83, 2907-2917.

15. Hayirli, A., Grummer, R.R., Nordheim, E.V., Crump, P.M., Animal and dietary factors affec- 
ting feed intake during the prefresh transition period in holsteins. J. Dairy Sci, 85,3430-3443.

16. Johnson, K.A., Johnson, D.E., 1995. Methane emissions from cattle. J. Anim. Sci., 73, 24832492.

17. Kara, Ç., 2009, Süt sığırlarının geçiş dönemlerinde kalsiyum propiyonat katkısının süt verimi ve bileşimi ile ketozis, hipokalsemi ve bazı döl verimi parametrelerine etkileri. Doktora tezi, Uludağ Üniversitesi Veteriner Fakültesi, Hayvan Besleme ve Beslenme Hastalıkları A.D., Bursa, Türkiye.

18. Lima, F.S., Sá Filho, M.F., Greco, L.F., Santos, J.E.P., 2012. Effects of feeding rumen-protected choline on incidence of diseases and reproduction of dairy cows, The Veterinary Journal, 193, 140 145.

19. McDowell, L.R., 1989. Choline. In: McDowell, L.R. (eds), Vitamins in Animal Nutrition - Comparative Aspect to Human Nutrition, Academic Press, Inc., NY, ABD, pp. 347-364.

20. Mohsen, M.K., Gaafar, H.M.A. , Khalafalla, M.M., Shitta, A.A., Yousif, A.M., 2011. Effect of rumen protected choline supplementation on digestibility, rumen activity and milk yield in lactating friesian cows. Slovak J. Anim. Sci., 44(1), 13-20.

21. Neill, A.R., Grime, D.W., Dawson, R.M.C., 1978. Conversion of choline methyl groups through trimethylamine into methane in the rumen. Biochemistry Journal 179, 529-535.

22. Oltenacu, P.A., Broom D.M., 2010. The impact of genetic selection for increased milk yield on the welfare of dairy cows. Animal Welfare, 19, 39-49.

23. Piepenbrink, M.S., Overton, T.R., 2003. Liver metabolism and production of cows fed increasing amounts of rumen-protected choline during the periparturient period, J. Dairy Sci., 86, 17221733.

24. Pinotti, L., Baldi, A., Dell'Orto, V., 2002. Comparative mammalian choline metabolism with emphasis on the high-yielding dairy cow, Nutrition Research Reviews, 15, 315-331.

25. Pinotti, L., Baldi, A., Cheli, F., Monfardini, E., Dell'Orto, V., 2000. Dairy cows peripartum feeding strategy: rumen protectedcholine supplementation. In: Zecconi, A. (eds) Proceedings of the Symposium on Immunology of the Ruminant Mammary Gland, Parma, pp. 261-263.

26. Reece, W.O., 2008. Dukes veteriner fizyoloji. Yıldız, S. (Çev.), Medipres, Malatya.

27. Santos, J.E.P, Lima, F.S., 2007. Feeding RumenProtected Choline to Transition Dairy Cows. http://dairy.ifas.ufl.edu/rns/2009/Santos.pd $\mathrm{f}$

28. Scott, J.M., 1999. Folate and vitamin B12. Proceedings of the Nutrition Society 58(02), pp. 441448.

29. Sharma, B.K., Erdman, R.A., 1988. Effects of high amounts of dietary choline supplementation on duodenal choline flow and production responses of dairy cows. J. Dairy Sci. 71, 2670-2676.

30. Sharma, B.K., Erdman, R.A., 1989. In vitro degradation of choline from selected feedstuffs and choline supplements. J. Dairy Sci., 72, 27712776.

31. Shawn, S.D., Rumen-Protected Choline, http://www.extension.org/pages/26158/rumenprotected-choline.

32. Umucalılar, H.D., Gülşen, N., 2005. Çiftlik hayvanlarında beslenme hastalıkları, S. Ü. Basımevi, Konya, Türkiye.

33.Zeisel, S.H., 1988. 'Vitamin-like' molecules. In: Shils,M., Young V. (eds) Modern Nutrition and Health and Disease. Lea \& Febiger, Philadelphia, ABD, pp. 440-452.

34.Zom, R.L.G., Van Baal, J., Goselink, R.M.A., Bakker, J.A., De Veth, M.J., Van Vuuren, A.M., 2011. Effect of rumen-protected choline on performance, blood metabolites, and hepatic triacylglycerols of periparturient dairy cattle. J. Dairy Sci., 94, 4016-4027. 
